\title{
Receptions of Revelations: A Future for the Study of Esotericism and Antiquity
}

\author{
Dylan Burns
}

There is no study of "esotericism" (hereafter referred to without scare quotes) in which the literature and legacy of the ancient Mediterranean world do not play a primary role. ${ }^{1}$ To take several examples, the so-called Yates paradigm derived from Frances Yates's celebrated work Giordano Bruno and the Hermetic Tradition may be understood as not just relating a history of a neglected Renaissance philosopher and practitioner of magic, but the reception and revival of ancient Platonism and Hermetism in the fourteenth and fifteenth centuries (Yates, 1964). The Yates paradigm has also been formative to Wouter Hanegraaff's many studies on (Western) esotericism, a history of modern "rejected knowledge" which deals in some way with the "gnosis" experienced by ancient philosophers making claims to eastern wisdom, a phenomenon called "Platonic Orientalism" (see below). Kocku von Stuckrad, meanwhile, has employed the term esotericism to denote wider cultural discourses that deal with the mediation of secrecy, concealment, and revelation of "absolute knowledge" in both antiquity and modernity, central topoi of which include Neoplatonism, Gnosticism, and Jewish mysticism (von Stuckrad, 2010; esp. von Stuckrad, 2015).

"Where there's smoke, there's fire." Specialists in the study of Mediterranean antiquity have already for some time been debating the difficult status of roughly the same body of ancient evidence (Burns, 2015b, p. 103). In early twentieth-century scholarship, one reads of a kind of "occult syncretism" of the later Roman empire, exemplified in Neoplatonic theurgy, a "spineless syncretism" which was "sucking the life-blood out of Hellenism," in Eric Robertson Dodds's memorable phrasing (Dodds, 1947, pp, 58-59). John Dillon's classic textbook The Middle Platonists closes with an appendix on what he loosely termed the "Platonic Underworld," i.e. Gnosticism, Hermeticism, and the Chaldean Oracles, viz. Neoplatonic theurgy (see below). ${ }^{2}$ Garth Fow-

1 For valuable comments and emendations to the present text I thank the volume's editors, Egil Asprem and Julian Strube, as well as Nicholas Banner. All judgments and especially errors therein remain, of course, my own.

2 Cf. Victoria Nelson's discussion of the theme of the "grotto" "as neither a garden ornament nor a chamber of horror, but a place of worship," exemplified by Hellenistic and Roman Alexandria, where Hermetic, Gnostic, and Platonic literature flourished (Nelson, 2003, p. 31). 
den's groundbreaking 1986 study The Egyptian Hermes located the Hermetic literature in a potpourri of ancient Platonism, Graeco-Egyptian religious syncretism, and ritual and alchemical texts which he dubbed the "Pagan intellectual milieu" exemplified by writers like the alchemist Zosimus of Panopolis (Fowden, 1993, p. 114). Perhaps aware of where these ancient materials lead in their modern afterlives, some historians and philologists have in recent years even taken to casually denoting this material "esoteric," as when Coptologist Stephen Emmel surmised that the Nag Hammadi Codices were produced by a network of "philosophically and esoteric-mystically like-minded people" (Emmel, 2008, p. 48).

In short, students of esotericism cannot avoid antiquity, and students of antiquity —or at least of ancient Platonism, Gnosticism, and magic - have not been able to avoid esotericism, either. One does not get far in the study of, say, Giordano Bruno, Paracelsus, or Carl Gustav Jung without running into the ancient sources discussed in the previous paragraph (although most scholars of esotericism have generally avoided in-depth engagement with them-Tommasi, 2016 pp. 10-18). Nor can one write effectively about the modern reception of these ancient sources without arriving at the topics the term "esotericism" is supposed to cover (on reception-history viz. ancient religion and esotericism, see Burns and Renger, 2019). Yet the question of "esotericism and antiquity" remains difficult to articulate in an effective way - much less answer-not least owing to the diversity of sources involved and the sequestering of the specialists who know them into university departments where interdisciplinarity remains verba non acta. The present contribution seeks to outline three of the primary lines of enquiry in the study of esotericism and antiquity, highlighting their challenges as well as promises. These are, first, the issue of the Platonic character of so much of the material at hand and its importance for the history of philosophy, particularly vis-à-vis the phenomenon of "Platonic orientalism"; second, the ever-problematic status of "Gnostic" literature and the terms "Gnosis/gnosis" and "Gnosticism"; and third, the relationship of this material to wider research on revelatory literature and phenomena. The essay will argue throughout that the answer to these problems, and the most promising methodological venue for new investigations, is not to carve out new phenomenological descriptions of "gnosis" or the "gnostic, esoteric, mystical," but to examine the reception-history of the ancient sources in question, particularly with respect to their status as competing claims to revelatory authority. 
Spelunking the "Underworld of Platonism" and the "Dark Side of Late Antiquity"

One could argue that the study of "Western esotericism" simply charts the complex reception-history and related developments, from the Renaissance through today, regarding the sources that Dillon refers to as "some loose ends" in the study of Middle Platonism: the aforementioned "Platonic Underworld" (on a similar note, Hanegraaff, 2012, p. 332). The very proximity of this "Platonic Underworld" and its reception to the subject of esotericism requires little elaboration here. It suffices to recall the example of the aforementioned E.R. Dodds, who in 1936 succeeded the great Gilbert Murray as Regius Professor of Greek at Oxford (Christ Church). An influential scholar of Greek literature, Dodds penned many famous articles and books and produced a handsome edition of the Neoplatonist Proclus's Elements of Theology, an epitome of dry, metaphysical scholasticism. This same man who decried the theurgy of the Neoplatonists (Marx-Wolf, 2016, p. 6o) also spent a lifetime investigating paranormal phenomena in modern London, serving as president of the Society for Psychical Research from 1961 to 1967 (Hankey, 2007, pp. 508-515; also Tommasi, 2016, p. 17). The history of the study of Neoplatonism - and as we will see, the notion of "Neoplatonism" itself-are of necessity bound to interest in and investigation of magic and occultism. What is less obvious is, firstly, the question of why (or even whether) this particular body of ancient Platonic material comprises a distinctive group in its ancient context; and second, how it came to enjoy disrepute among scholars, as it did with Dodds. Put differently: is it meaningful to speak of such a thing as "esotericism in antiquity" vis-à-vis the "Platonic Underworld"? And regardless of how the first question is answered, why did such a notion appear, with pejorative connotations, in scholarship?

The characteristics of the "Platonic Underworld" were delineated by Dillon as follows: Valentinian Gnosticism, the Corpus Hermeticum, and the Chaldean Oracles all derive existence (even that of matter) from one, supreme first principle; they distinguish between this principle and a creator-deity who is "directly responsible" for the world's creation; they describe a "pervasive female principle responsible for multiplicity, differentiation, and the generation (and ultimate salvation or return) of all lower existence"; and they make consistent use of imagery drawn from the Platonic dialogues which were also central to Middle Platonism, such as "Light against Darkness, the inexhaustible Fount of Being, and the wings of the Soul" (Dillon, 1996, p. 396). Such literature testifies that "the influence of the Platonic world-view penetrated very widely into the seething mass of sects and salvation-cults that sprang up within the Greco-Roman world in the first two centuries A.D." (Dillon, 1996, p. 396). In 
her introduction to a critical edition of the Chaldean Oracles, Ruth Majercik appropriated Dillon's phrase, and revised his description into the following typology.

1. "Elaborate and often exasperating metaphysical constructions";

2. "An extreme derogation of material existence";

3. A dualism in which the soul or mind is a "spark" trapped in the material body;

4. A "method of salvation" which involves "spiritual and/or ritual ascent";

5. A "mythologizing tendency" that renders abstract hypostases in vivid terms.

Majercik noted further the important "personal function" (i.e., soteriological function) played in this literature by female mythological figures, "operating at all levels and directly responsible for material creation," such as Sophia/Pronoia/Epinoia, Nature, and Hecate (Majercik, 1989, pp. 3-5).

While these typologies are rarely invoked in the secondary literature today, their rhetoric of marginality or exclusion persists in scholarship that treats the "Underworld" Platonist literature in its antique context. Luciana Soares Santoprete, for instance, has recently employed the differentiation between "mainstream" and "marginal" Platonisms even as she has challenged it. While she rightly emphasizes how all Platonic literature shares a "common heritage" in regarding Plato as authoritative and how important (i.e., non-marginal) the "Underworld" was for the ancient Platonists themselves, she also organizes much of the research agenda for this literature under the working title Il lato oscuro della Tarda Antichità ("the dark side of late antiquity" - Soares Santoprete, 2016, pp. 10-11, 14-16). Chiara Tommasi, in a paper from a conference devoted to the subject of "the dark side of late antiquity," grants some "marginality" to the "Underworld" dossier, which she takes to "come close to the areas pertaining to Western esotericism" (Tommasi, 2016, pp. 15-16). Rather than describing these esoteric Platonisms with reference to Dillon or Majercik, Tommasi highlights more general features they share, such as "innovation" and a tendency to secrecy (i.e., esotericism in a basic sense), with ramifications for the later orthodoxy and orthopraxy within the Platonic tradition (Tommasi, 2016, pp. 26-29).

The "Platonic Underworld" or "dark side of late antiquity" are, at least in their ancient contexts, misnomers. Most obviously, the metaphors do not fit. None of the literature is katagogic, i.e., concerned with journeys to the underworld—as Majercik notes, it is uniformly anagogic, concerned with the ascent of the soul. Light and the sun, not darkness and the earth, are among the most predominant images this literature uses to describe the divine. Nor is there much internal coherence to the various articulations of this "Under- 
world literature."3 "Dualism" is a contested category, and while it may be useful in certain cosmogonic and anthropogonic contexts, it has little purchase in Dillon and Majercik's application to soteriological contexts (see e.g. Stoyanov, 20oo, pp. 2-5). Heavenly ascent or anagogic soteriology are so commonplace in late ancient Mediterranean spirituality that they hardly constitute a criterion for distinction (for survey, see Segal, 1980). Nor is the theme of the divine "spark" trapped in human bodies (highlighted by Majercik) a universal to these "marginal Platonisms"; even within Gnostic sources, it is actually a rare motif (Burns, 2015b, pp. 81-82; see also Chaldean Oracle 44 in Majercik, 1989, p. 66). More successful is comparison of the female deities which are responsible for producing matter (for a follow-up, see Turner, 2016), and Soares Santroprete and Tommasi are right to point to the innovative character of the literature in question, so much of which seems to coalesce around the remarkable synthesis of Plotinus in the mid-third century CE. Particularly acute is the role played by Gnostic literature in the formation of the thought we see in him, Porphyry, and the anonymous Commentary on Plato's 'Parmenides' (Soares Santroprete, 2016, pp. 17-35; see now Mazur 2020). The interplay of Gnostics and Platonists in the third century is all the more alluring given how vociferously Plotinus and Porphyry came to denigrate their Gnostic contemporaries, exiling them from inclusion in their construction of the tradition of Plato and Hellenic philosophy more generally (see Burns, 2014; cf. also Banner, 2018, pp. 135-137).

Finally, Majercik is right to point to the predominance of both myth and ritual, but this cannot be because ancient Platonists did not employ myths or practice rituals. On the contrary, "mainstream" Platonists were deeply interested in Plato's myths and allegorical exegesis of a range of mythological sources (Lamberton, 1986). Even if one reads Plotinus and Porphyry as distant from cultic concerns (which one need not do-Burns, 2014, pp. 18-19), the Platonist tradition following them is exemplified by its hieratic turn, extending from Iamblichus at the end of the third century CE to Damascius in the mid-sixth century. The beginning of this turn is marked by the debate between Porphyry and Iamblichus about the mechanics of theurgy and ritual practice, with chief reference to magic (Marx-Wolf, 2016). Rather, the question is which myths and which cultic practices became "mainstream" among Platonists. ${ }^{4}$ While later Platonists regarded the Chaldean Oracles, Orphic lit-

3 I confine myself to Majercik's typology, as it is the most developed out of the analyses reviewed in the above.

4 Cf. Hanegraaff, 2012, p. 13, arguing rather that the "underworld" is a pejorative term used by historians of philosophy to decry religiously-inclined Platonic literature; similarly Hanegraaff, 2016, p. 382 . 
erature, and (less often) Hermetic texts as authoritative sources of revelation, biblical sources all but disappeared from serious discussion following the aforementioned Plotinus-Gnostic controversy in the 26 os CE, except to be criticized or excoriated (Burns, 2014, pp. 147-154). Conversely, as Ilinca TanaseanuDöbler has shown, the Neoplatonists' discussions of theurgy were not merely disagreements over the mechanics of ritual, but also vehicles for competing constructions of "the Platonic tradition" (Tanaseanu-Döbler, 2013). ${ }^{5}$ It is to these constructions of revelation and authority with regards to the Platonic tradition — and the origin of this tradition's 'marginal' character — that we now turn.

\section{Seeking Platonic Orientalism in Ancient Alexandria — and Early Modern Germany}

The Gnostic, Hermetic, and "Chaldean" theurgic literature encompassed by the notion of the "Platonic Underworld" has sometimes been taken as coterminous with "Platonic Orientalism" (as by Hanegraaff, 2012, pp. 12-14). This latter term was coined by James Walbridge in a study of the twelfth-century Persian Illuminationist and Neoplatonist Suhrawardì to denote the proclivity of Platonists in general to extol a primeval "wisdom of the East," a philosophia perennis known by pre-Hellenic civilizations superior to Greek philosophy (Walbridge, 2001). It is central to Hanegraaff's seminal claim that Western esotericism is "the polemical Other of modernity," a philosophia perennis identified with a "paganism" infused with "cosmotheism" and "gnosis" (Hanegraaff, 2012, pp. 370-374; see also Tommasi, 2016, pp. 21-24). In more recent work, Hanegraaff identified gnosis as the object sought by "a kind of 'transconfessional' cultic milieu that flourished particularly in Egypt, and whose adherents - whether they were pagans, Jews, or Christians - all interpreted (Middle) Platonic metaphysics in such a way as to transform it into religious worldviews," seeking "the ancient and universal spiritual wisdom...of the Orient and their legendary sages..." (Hanegraaff, 2016, p. 381). "The possibility," Hanegraaff argues, "of gaining direct access to the realms of light by means of ecstatic states was inherent in Platonic Orientalism," which was chiefly concerned with obtaining gnosis through altered states of consciousness (Hanegraaff, 2016, pp. 383, 387-388). Hanegraaff is of course correct that narratives

5 Acknowledging this insight does not mean one has to agree with Tanaseanu-Döbler's excessive agnosticism about whether theurgic evidence testifies to actual ritual practices among the Neoplatonists (Tanaseanu-Döbler, 2013, esp. pp. 284-285). 
which identify ultimate wisdom as being both primordial and derived of some "eastern" (or better, "barbarian"- see below) provenance are central to both the notions of the "Platonic Underworld" and the greater relationship of esotericism to antiquity.

Yet our evidence about Platonic Orientalist discourse is not concerned with ecstatic experiences of "gnosis"; it is concerned with revelatory authority, namely, which authorities get privileged, and which teachings and practices associated with these authorities are thereby legitimated. This is not to say that texts that make use of Platonic Orientalist discourse say nothing about mystical experiences or altered states; rather, the questions of authority that Platonic Orientalism engages are distinct from speculations about mystical experiences. Moreover, narratives about ancient, barbarian wisdom are sometimes used to subordinate the authority of the barbarian (i.e. non-Greek) peoples. As much is obvious by looking at the most famous and widely-cited example of Platonic Orientalism, fragment 1a of the second-century CE Platonist Numenius of Apamea, which argues that the correct procedure of theological investigation is:

to go beyond the evidence of Plato and join it with the sayings of Pythagoras. Then, one must appeal to the justifiably famous nations, addressing their rituals, doctrines, and accomplishments in agreement with Plato (Platōni homologoumenōs), insofar as Brahmins, Jews, Magi, and Egyptians are in accord with one another. (trans. mine, text in des Places, 1973, p. 42)

There is nothing here about "gnosis" or altered states of consciousness. More interesting is how we construe the adverbial phrase Platōni homologoumenōs. It modifies the accomplishments, etc. of the non-Greek nations (rightly Hanegraaff, 2012, p. 12: "which they accomplish in full accord with Plato"). Yet this does not mean that the non-Greek sources have a wisdom superior to Plato; rather, the sense is that one should make use of them only to the extent that they agree with Plato.

Numenius then practices a type of Platonic Orientalism that extols the "wisdom of the east" even as it subordinates it to more familiar Hellenic authorities, particularly Pythagoras and Plato (whom Numenius understood as a great Pythagorean; see further Banner, 2018, pp. 102-103). Such an approach typifies his exegesis of extra-Hellenic sources in his other extant fragments, which are almost exclusively concerned with Hellenic authorities, and which use a Hellenic lens to reinterpret extra-Hellenic sources. While some Platonists (such as Plutarch, or Plato himself) did regard true wisdom as belonging to peoples 
antecedent and superior to the Greeks, the bulk of our evidence from Greek philosophical and rhetorical literature in the Roman Empire tends towards Numenius's view of Hellenic teachers as "first among equals" - that is, first. What is so remarkable about the Orientalizing discourse of the Hermetica, the Chaldean Oracles, and many Gnostic sources is the way they "auto-orientalize," insofar as they present their deeply Platonic teaching in eastern dress (for survey, see Burns, 2014, pp. 20-28).

Is it worth to continue speaking of "Platonic Orientalism" at all? I do think so, despite the misgivings of Liana Saif (2021, pp. 72-74). Saif argues that the term "orientalism" is misleading, since it is lacking in our sources. Moreover, the element of colonizing, exploitative power dynamics that is integral to Edward Said's coinage of said term is not adequately dealt with in scholarship on "Platonic Orientalism." To take the second argument first, the reading of Numenius offered here highlights that Platonic Orientalist rhetoric was often exploitative and subordinating. While modern colonialism postdates antiquity, exploitation, empire, and the complications of negotiating complex ethnic identities do not (also Tommasi, 2016, pp. 21-23). The question of how power figured into the development of Platonic Orientalist-or "barbarizing philosophical," if one wills-discourses is a promising trajectory for investigation. Indeed, so many of the individuals who participated in and developed it were themselves Hellenophone elites who initially hailed from the upper strata of Roman Syrian society (see further Burns, 2014, pp. 15-16; also Tommasi, 2016, p. 24; for a stimulating if somewhat different account, see Johnson, 2013). As for Saif's first argument, it is worth noting that some scholarship on the phenomenon here denoted "Platonic Orientalism" has preferred the phrase "barbarian wisdom," which much more closely approximates the phraseology in the ancient sources. Perhaps this is for the best; one could even add that "Platonic Orientalism" is misleading insofar as the fetishization of barbarian wisdom was hardly exclusive to Platonic-Pythagorean literature (e.g. non-Platonizing writers from the Second Sophistic such as Philostratus). At the same time, such fetishization is so central to Platonic literature that to denote it as "Platonic" is hardly a red herring (cf. the suggestion of "Platonist perennialism" - Banner, 2018, pp. 91-101). Meanwhile, the term "barbarian" can be misleading as well, insofar as the Greek term barbaros connoted exclusion from Greek or, later, Roman identity — including, say, Hellenophone Jews and Christians living under the Roman Empire (LSJ 306b; PGL 289a). Numenius did not fetishize just any barbarians. Rather, the regions he designated as bearers of hoary barbarian teaching - those identified with the Persians, the Chaldaeans, the Indians, the Jews, and above all, the Egyptians_-overlap closely with those Said identifies as the "Orient" avant le lettre. 
In short, the mythological and cultic aspects of the "Platonic Underworld" are hardly uniform, because Gnostic, Hermetic, and Chaldean/theurgic sources all made competing claims to revelatory and cultic authority, claims that Platonists from the mid-third century on did not necessarily regard as commensurate with one another. It is not sufficient to trade the "Underworld" out for "Platonic Orientalism," because the latter category denotes a variety of approaches to eastern wisdom among Platonists, among them a subordinating, exploitative discourse that is distinct from the auto-orientalizing one finds in the "Underworld" texts, to say nothing of any connotations of gnosis or ecstatic states. What rings true in the category of the "Platonic Underworld" is its denotation of these materials as marginal in some sense. Something happened to this material that made us, and centuries of our forebears, understand it this way. Remarkably, no earlier studies on the "Underworld" or the "dark side of late antiquity" ask whence this marginal status derives (on Hanegraaff's "grand polemical narrative," cf. however Tommasi, 2016 pp. 15-18; see also Asprem, 2021).

If we want to understand where on the road these Platonisms entered the grotto, so to speak, a reception-historical approach is a good place to start. There are many leads. While they all disrupt the notion of a "Platonist Underworld" coexisting along a "mainstream" Neoplatonism, they also remind us how many early modern writers identified the sect of the Neoplatonists with that of the Gnostics, erasing the sharp line Plotinus and Porphyry tried to draw between themselves and their Gnostic interlocutors. Leo Catana has recently shown how the conceptual underpinnings of the distinction between Middle Platonism and Neoplatonism go back to the Lutheran Johann Jacob Brucker's Historia critica philosophiae (1742-1767), which distinguished between earlier Platonists and the systematizing "eclectics" of Alexandria such as Plotinus, possessed of an inclination towards enthusiasm and distorted by its emergence in Egypt (Catana, 2013). Julian Strube's studies of the socialist background of nineteenth-century occultism highlight how often histories of socialism and communism from the 1830-185os identified it as an early Christian heresy with pretensions to a universal, esoteric philosophy devised by Platonists, Pythagoreans, and Gnostics in Roman Alexandria (Strube, 2016, pp. 111-121, 206, passim; Strube, 2017b). Romantics and Transcendentalists on the other side of the Atlantic seized upon Neoplatonic authors and legends of ancient Alexandrian wisdom in formulating their own, distinctively American but "universal" non-sectarian philosophy, which had a profound influence on Blavatsky's Secret Doctrine (Bregman, 2016, esp. pp. 311-312; more widely, Gutierrez 2014). No less influential an authority than G.W.F. Hegel identified Neoplatonism as the philosophy of Platonist Alexandria responsible also for 
giving us "Kabbalistic philosophy" and "Gnostics" (Perkams, 2017, pp. 4-5). The emergence and deprecatory character of the "Platonic Underworld" is thus bundled not only with historiography of magic and the occult, as the example of Dodds showed, but with the very emergence of the category of "Neoplatonism" and related terms, and the relationship of these terms to the mythic School of Alexandria and the "Gnostics."

\section{3}

\section{Getting to Know "Gnosis" and "Gnosticism"}

Among the three "Underworld Platonisms," Gnosticism-the body of evidence regarding the teachings of individuals who in antiquity reportedly called themselves "Gnostics" (gnōstikoi, Grk. "knowers"; Layton, 1995) assumes special importance. One reason, remarkably underappreciated in scholarship today, is that our Gnostic sources have a very different receptionhistory than do the other inhabitants of the "Platonic Underworld." A second reason is the famous terminological fog around the complex of terminology related to Gnosticism. These two issues are related, and appreciation of the former helps us resolve serious problems with the latter, particularly regarding the deeply problematic employment of the term "gnosis" as an etic category in the study of philosophy and religion — a usage which, I will argue, should be abandoned.

Our ancient reports about "the Gnostics" and their literary compositions are largely limited to the second-fourth centuries $\mathrm{CE}$, with some reports extending further into late antiquity until the rise of Islam. At this point sources about the Gnostics for the most part vanish, with scattered quotations, adaptations, and rumors littering our sources through the end of the first millennium (for recent survey, see Burns, 2019a). Meanwhile, Hermetic, Neoplatonic, and theurgic literature mostly went under the radar, having nearly entirely disappeared in the Latin West while being handled gingerly in Byzantium, before being reintroduced to Western Europe at the end of the fifteenth century. Now, as discussed above, these Neoplatonic and Hermetic "Underworld Platonisms" became identified with the mysterious figures of the Gnostics themselves and the greater notion of an eclectic, Alexandrian Platonism. Yet while one could read translations of Neoplatonic and Hermetic works, for any information or accounts about the Gnostics, one was left to their opponents: the "proto-orthodox" heresiologists.

Thus, our notions about Gnostics, gnosis, and Gnosticism developed over the last two millennia largely without reference to available "Gnostic" primary texts, and so the notion of the "Gnostic" has for the vast majority of its his- 
tory been employed as a term of "othering," albeit with reference to a very loose body of clichés, such as elitism, anticosmism, moral licentiousness, and so forth (Hanegraaff, 2016, p. 385). The great power of this history of othering and its attendant accretions is at the heart of scholarly calls for dismissal of "Gnosticism" and "the Gnostic" as a set of historical categories used to denote the primary sources we possess today which actually do contain the compositions by, or related to, the ancient "Gnostics" (Williams 1996; King 2003): ancient Egyptian codices with texts in the Coptic language. These books were unearthed only in modernity, having spent the centuries from late antiquity until today buried in the sands of Egypt; during that time, the discursive construction about these books' contents - of the Gnostics as a kind of 'other' connected to a Platonist School of Alexandria-developed on its own. Consequently, these terms must be used with care when interpreting this ancient Coptic evidence.

Yet debate about the viability of the terms "gnosis" and "Gnosticism" have hardly addressed the status of this terminology from the vantage point of the reception-history of the Coptic Gnostic corpus itself. Here, there is much work to be done, and all of it relates directly to esotericism: Codex Askewensis (Pistis Sophia) and Codex Brucianus only appeared in England towards the end of the eighteenth century, and were not translated into a modern language until the last quarter of the nineteenth. The Berlin (or "Achmim") Codex (BG 8502) was not published until 1955, and the Tchacos Codex was first published in 2006. The greatest hoard of our Gnostic primary sources by far, the Nag Hammadi Codices, was not discovered until December of 1945, nor made available in mass publication until 1977, when development of its scholarly interpretation was only beginning. Many of the terms of this scholarly interpretation were set not by the Nag Hammadi texts alone, but by the initial popularization of scholarship about the Askew and Bruce Codices—led above all by the Theosophist G.R.S. Mead (Burns, 2019b; further, Winter, 2019). Other early readers of Codex Askewensis in the later nineteenth century sought to understand it chiefly with reference to the newly-published Egyptian ritual texts known today as the Papyri Graecae Magicae (P.G.M.-Burns, 2019a, pp. 16-17). We are only beginning to understand the impact of this initial, pre-Nag Hammadi wave of interpretation of the Askew and Bruce Codices on scholarship about the greater Coptic Gnostic corpus. Conversely, the reception of the P.G.M. among contemporary occultists remains tied to the language of "Gnostic(ism)" (Johnston, 2019). While it is widely understood that C.G. Jung had an enormous interest in Gnosticism (see e.g. Hanegraaff, 2012, pp. 288-289; DeConick, 2016, below), research on the great importance of Jungianism for the phenomenon of Neo-Gnosticism remains relatively primitive (Burns, 2007, pp. 267-272; now esp. Hammer, 2019). Scholarship on the peculiar history of reception of Nag 
Hammadi Codex I - the purchase of which the tsar of the study of Gnosticism in the twentieth-century Netherlands, Gilles Quispel, brokered for the Jung Institute in Zürich in 1951-has scarcely begun (see now Given, 2019, esp. 94-96).

On the other hand, the fact that the Coptic Gnostic corpus sat buried and unavailable while the "Gnostic" terminology we today use to describe it was being developed in connection with other "Underworld Platonisms" in the Renaissance and Early Modern periods may be a key for understanding the "Underworld" literature in new ways. A doyen of Gnostic and Coptic studies alike, Bentley Layton, sensed as much in his opening remarks at the 1978 International Conference on Gnosticism at Yale University, which set an entire generation's scholarly agenda for research on Nag Hammadi and Gnosticism:

At the time of the Renaissance, scholars thought they could rediscover a Prisca theologia from which had sprung the transcendental wisdom of the West. Indeed Plato himself had hinted playfully at its existence; and the Florentine humanists believed they had found it, and published it, in the writings of Mercurius Trismegistus. Only generations later was the Hermetic Corpus unmasked as the work of Gnosticizing Platonists, probably contemporary with Valentinus and the Sethians and themselves engaged in the self-same search that had so fascinated Ficino and his patrons; while the fraudulent Horapollo continued to exert an influence until Champillon's decipherment.... (Layton, 1980, pp. xi-xii)

Layton then muses upon "the possibility that earliest Christianity and therefore Christian culture developed under the influence of a Gnostic competitor or even precursor," a different enquiry which has since largely exhausted its usefulness (Layton, 1980, p. xii). Yet his insight remains: the best way we can understand the intellectual and cultural context from which the Nag Hammadi Codices came, alongside Christianity, is the "Platonist Underworld" literature of "Mercurius Trismegistus." ${ }^{6}$ For our purposes, the inverse of this point is worth highlighting: our Coptic Gnostic manuscripts furnish us a window into the "Platonic Underworld" prior to its Renaissance and Modern-era receptions and transformations into esotericism. They give us a peek into what the "School of Alexandria," loosely construed, looked like before the tradition of it as "marginal" and "eclectic" was invented. This is a vast task that remains to be taken up-except, perhaps, where scholars have been working on Gnosticism in terms of the history of philosophy (see above), and yes, in terms of esotericism.

6 Tellingly, Hermetic texts are found in Nag Hammadi Codex vi, and Codex Tchacos contains, following the infamous Gospel of Judas, a Coptic Hermetic tractate. 
It is precisely here that we meet the other terminological difficulty in the study of Gnosticism: the question of the relationship between the terms "Gnosticism" and "gnosis." I have tackled this question in some detail elsewhere (Burns, 2015a, pp. 27-29; Burns, 2019a, pp. 17-20) and so restrict myself to brief remarks here. While the modern category of "Gnosticism" as used by Layton (1995) to denote the complex of evidence around individuals reputed in antiquity to call themselves "Gnostics" has undergone extensive critique, there is precious little theorization of the category of "Gnosis/gnosis," a fact which is all the more remarkable given that the term currently enjoys a resurgence. The term "Gnosis" (capitalized) has a long history in Continental scholarship as a synonym for what Layton called "Gnosticism," but it has just as often been used to refer to something distinct from "Gnosticism," usually relating to religious currents based upon salvific knowledge (the ostensible "gnosis").

This latter usage has become pivotal to explorations of the relationship between esotericism and antiquity. In fact, it is employed more or less as a shorthand for "ancient esotericism," or even simply "esotericism" from antiquity to today. For Hanegraaff, as discussed above, "gnosis" refers to the experience of an altered state of consciousness, which was the primary interest of adherents to Platonic Orientalism - the backbone of Western esotericism. A Dutch pioneer in the study of Gnosticism and Coptic literature, Roelof van den Broek, ${ }^{7}$ distinguishes the dualistic teachings of the Gnostics from the greater current of "gnosis": "an esoteric, that is partly secret, spiritual knowledge of God and of the divine origin and destination of the essential core of the human being which is based on revelation and inner enlightenment, the possession of which involves a liberation from the material world which holds humans captive" (van den Broek, 2012, p. 3; similarly Yates, 1964, p. 22; Shaw, 2019, pp. 70-71; Versluis, 2019). This "gnosis" is exemplified by relatively non-dualistic literature such as the Hermetica or the Gospel of Thomas, in contrast to the cosmological dualism common to Gnostic sources, but it is hardly limited to a distinctive social group or even to antiquity (van den Broek, 2012, pp. 8, 11). April DeConick, meanwhile, eschews the language of "gnosis" for "Gnostic spirituality," a form of transgressive, religious mentality or epiphany that transcends adherence to an established religious tradition and emphasizes one's proximity if not identity with the divine (DeConick, 2016, pp. 11-13, 68-70; also Shaw, 2019, pp. 69, 76). DeConick identifies four "Gnostic awakenings" following the suppression

7 On the pivotal role van den Broek played in the establishment of the Chair for the History of Hermetic Philosophy and Related Currents (GHF) at the Universiteit van Amsterdam, see van den Broek, 2009. 
of Christian Gnostics in antiquity: (a) the medieval dualisms of the Paulicians, Bogomils, and Cathars; $(b)$ the Renaissance Platonism that blossomed in the wake of Ficino's translations of ancient Platonic and Hermetic literature; $(c)$ the discovery of the Bruce and Askew Codices, and their reception by the Theosophists and Carl Gustav Jung; $(d)$ and the discovery, translation, and reception of the Berlin, Nag Hammadi, and Tchacos Codices (DeConick, 2016, pp. $\left.347-35^{\circ}\right)$.

Hanegraaff and DeConick's respective descriptions of "gnosis" or "Gnostic spirituality" shy away from the language of a "Gnostic religion" (Hanegraaff, 2016, pp. 384-385; DeConick, 2016, p. 10; not so van den Broek, 2012, pp. 1-3, who writes freely of "Gnostic religion" as based upon "gnosis"). Yet this is old wine in new wineskins: a religious current that extends from antiquity, particularly the milieu of Roman Egypt (home to Alexandria, of course), until today. Its basis is a secret, salvific knowledge (hence the term "gnosis") obtained through revelatory or ecstatic experiences and distinct from the dualistic myths of the ancient Gnostics, who nonetheless serve in this narrative as the masters of salvific "gnosis" par excellance. The coincidence of this "Gnostic religion" with some notion of "ancient esotericism" is obvious: Hanegraaff's Platonic Orientalism, van den Broek's "Gnostic mentality," and DeConick's "Gnostic spirituality" all seek to tell a story about the same things that other scholars have called Western esotericism (explicitly so for Hanegraaff, as discussed above; also van den Broek, 2012, p. 10; cf. DeConick, 2016, p. 16). One difficulty of such an approach was highlighted in the previous section: by assimilating claims to universal revelatory authority to a kind of philosophia perennis, it erases the way in which such claims seek to exclude competing traditions and revelations. To wit, if the Hermetica, the Gospel of Thomas, and Renaissance Platonism are all adherents of "gnosis" in some sense, then why do they disagree so much about the sources of supposed "gnosis" and the sort of revelatory and cultic traditions which are related to it? Second, do we not invite terminological confusion by using such closely related expressions for distinct phenomena: the "Gnosticism" of the ancient, dualistic "Gnostics," versus the "gnosis" of Western esotericism or "Gnostic mentality/spirituality"? And third, do these histories of "gnosis," so sharply demarcated from the cosmological dualism of ancient Gnostic and Manichaean literature, simply give us histories of "mysticism" under another name? Is it cosmological dualism or a more general sense of a mystical affinity of human and divine which is at stake in so much of the reception-history-among Theosophists, occultists, Jungians, and Neo-Gnostics - of the notion of "Gnosticism" and the Coptic Gnostic literature (see esp. Dillon, 2019, pp. 208-210)? Are non-marginal, relatively orthodox mystical works, such as those of the Cappadocian Fathers or 
the Corpus Dionysiacum, also exemplary of "gnosis" (also Burns, 2015a, p. 24; more generally, von Stuckrad, 2013; cf. Costache 2019, for whom "Christian Gnosis" seems coterminous with "Christian mysticism")?

Finally, do these scholarly histories of "gnosis/Gnostic spirituality" distinguish themselves sharply enough from the sort of "ancient wisdom narratives" that our primary sources draw up for themselves? Hanegraaff and van den Broek, for instance, identify "gnosis" as the third, suppressed, governing epistemological category of "Western culture," next to "faith" (revealed religion) and "reason" (Hanegraaff, 2012, p. 372; similarly van den Broek, 2012, pp. 1, 5; DeConick, 2016, prefers the language of "revolutionary spirituality"-pp. 4, 12, passim). The "faith-reason-gnosis" triad was pivotal for the aforementioned Quispel (Quispel, 2008, esp. pp. 143-146; see also Faivre, 2010, pp. 102-104). ${ }^{8}$ Curiously enough, it also appears in the introduction of the first translation (1917) into English of the untitled Gnostic treatise in the Bruce Codex, by the Vicar of Leeds, Rev. Alfred Amos Fletcher Lamplaugh (Burns, 2019b, pp. 68-69). As Hanegraaff has shown, this faith-reason-gnosis triad goes back to the seventeenth-century anti-apologetic Protestant Jacob Thomasius, as well as the aforementioned Jacob Brucker. With Jacques Matter, the first writer to refer to ésotérisme in French, the term "gnosis" became used in a popular way to denote the universal teaching of the Gnostics and Neoplatonists which flourished in ancient Alexandria (Hanegraaff, 2012, pp. 101-107, 148-152 passim; Hanegraaff, 2016, pp. 385-386; further, Faivre, 2010). Strube has demonstrated that the earliest historiographies of socialism explicitly denoted socialism and communism as belonging to a heretical tradition of "gnosis" from Roman Alexandria, a development directly tied to Matter's coinage of the term "esotericism" as well as emergent scholarship on "mysticism," "theosophy," and "kabbalah" (Strube, 2016, pp. 399-416, 524, 528, passim; Strube, 2017b). Through the literary mediation of a former socialist writing under the pseudonym Éliphas Lévi (Strube, 2017a), Matter's positive sense of "gnosis" floods the literature of the Theosophical Society, where gnosis, the "One Religion," a "divine science," transcends the boundaries of religious identities or traditions as well as the teachings of the philosophers and scientists. ${ }^{9}$

8 Van den Broek and Hanegraaff, meanwhile, were of course familiar with Quispel as a senior colleague in the Netherlands. DeConick worked closely with Quispel in her early career, and her Doktorvater, Jarl Fossum, earned his own doctorate under Quispel (DeConick, 2008).

9 For these phrases, see Mead, 1906, pp. 6-9, 359. An investigation of the notion of "Gnosis" in the literature of the Theosophical Society would be an enormous (and exhausting) task, but good places to begin would be volume two of Blavatsky's Isis Unveiled, or the second edition (1906) of Mead's Fragments of a Faith Forgotten (particularly pp. 29-32, a discussion recalling the faith-reason-gnosis triad). 
Much about the road from Thomasius, Brucker, and Matter via Lévi to Blavatsky and Mead, and from them to Lamplaugh and Quispel, remains unclear. Yet it is evident that the centuries of use of "gnosis" as an emic category by theologians and theosophists alike render it a burdensome, even disqualifying, term for use in in the etic historiography of philosophy and religion. ${ }^{10}$ If the scholar of Platonism - to say nothing of Gnosticism or esotericism - wishes to maintain any etic posture, he or she cannot proceed further with "gnosis" as such. Again, a reception-historical approach would be more methodologically viable for the professional historian, and also open up rich, new trajectories for research. It has long been recognized that the language of "gnosis" played an important role in Continental theology and philosophy of religion of the eighteenth and nineteenth centuries, but this context and its ramifications for our use of the category in theology and religious studies today has hardly been studied (see Koslowski, 1988; also Hanegraaff, 2016, pp. 386-387). Meanwhile, "gnosis" has long served as a standard term in the translation of Buddhist texts; a pioneer of twentieth-century philology of Sanskrit and Pali literature, Edward Conze, even called himself a "gnostic" (Burns, 2016, p. 9; Versluis, 2019, pp. 22-23). These and other receptions of the notion of "gnosis" do not demonstrate a "survival of Gnostic spirituality" (DeConick, 2016, p. 17). They illustrate how important the language of "gnosis" has been for people to declare, decry, and distance themselves from claims to the possession of revelations, particularly those relating to the "Platonic Underworld."

\section{Receptions of Revelations and Ancient Esoteric Traditions}

Scholarly theorization of the category of "gnosis" often focuses on its revelatory quality, or the direct apprehension of higher reality (Hanegraaff, 2012, p. 372; Hanegraaff, 2016, p. 381; van den Broek, 2012, pp. 2-3; DeConick, 2016, pp. 12, 15, 17 passim). What is at stake in scholarly discussion of "gnosis" (as distinct from "Gnosticism" and "Gnostics") are competing claims to authoritative revelations, and the cultic or ritual practices associated with them. Moving the conversation from "gnosis" to "revelation" may bring not only terminological clarity, but, again, open up fruitful and hitherto neglected trajectories of investigation, above all the interface of Biblical literature and scholarship

10 Similarly unhelpful are the calls—usually from those who have tenure-to turn attention away from historical analysis towards the study of the "subjective experience of gnosis" and the like (e.g. Shaw, 2019, pp. 68-70). 
about it (see further Burns, 2015a, pp. 24, 27-29). Theoretically speaking, if we roughly follow von Stuckrad in taking esotericism to be the purposeful implementation of the dynamic of secrecy, concealment, and revelation, then any esoteric claim necessarily implies the promise of revelation, with the converse that all revelations have been withheld and concealed prior to their unveiling. A happy consequence of this move is the necessary implication of apocalyptic (i.e., revelatory) literature and phenomena, biblical and non-biblical alike, in the study of esotericism.

Meanwhile, on the socio-historical plane, developments relating to the "Platonic Underworld," Platonic orientalism, Gnosticism, and magic in antiquity were not insulated from ancient Judaism or Christianity and related biblicizing movements, such as Manichaeism and Mandaeism. This fact is so obvious that it requires no illustration here, yet scholarship conducted today under the aegis of Western esotericism has for the most part proceeded with at best limited engagement with biblical studies and its attendant (often theological) institutions. Fortunately, the self-partitioning of the study of esotericism from biblical studies has not been reciprocal. April DeConick has done a great deal to promote the study of "Gnosticism, Mysticism, and Esotericism" at meetings of the Society of Biblical Literature, and the last decade has seen important publications that tackle questions of secrecy and concealment in biblical literature and ancient Judaism (Vander Stichele and Susanne Scholz, 2014; Coblentz-Bautch, 2015; Stone, 2018). Will scholars of esotericism read them?

Even study of the emergence of our categories governing parabiblical literature and its reception-history necessarily lead us to materials of interest to scholars of esotericism. Our chief sources for ancient and medieval understandings of the all-important personage of Enoch-a central figure of reference in Renaissance and early modern divination (Asprem, 2012) - are of course the "Ethiopic," "Slavonic," and "Hebrew" apocalypses which bear the patriarch's name. These texts are central to the greater category of "Old Testament Pseudepigrapha," works that transmit so much ancient and medieval Jewish and Christian lore and that have shed so much light upon the evolution of biblically-oriented religions, including Gnostic materials. The early stages of reception of the "Old Testament Pseudepigrapha" were dominated by seventeenth and eighteenth-century anxieties about the authoritative status of revealed Scripture following the Reformation and competing, newly-uncovered and newly-translated "heretical," revelatory authorities (Reed, 2009) —a central context for the receptions and inventions of "gnosis" and the "School of Alexandria" alike. We are in a similar situation with the so-called "New Testament Apocrypha," the reception and invention of which is closely related to that of the Old Testament Pseudepigrapha (Reed, 2015). More recently, 
Enochic Pseudepigrapha and the Dead Sea Scrolls discovered at Qumran in 1947 (less than two years after the discovery of the Nag Hammadi Codices) have come to acquire authoritative status among New Religious Movements closely related to New Age and esoteric milieus and practices (Kreps, 2019). The same could be said of "New Testament Apocrypha," which, together with works from the Coptic Gnostic corpus, are often packaged for New Age, NeoGnostic, or "esoteric" readership as revealing a lost or hidden Christianity, whose content addresses contemporary alternative religious concerns (Burns, 2007; Burns and Radulović, 2019; Kreps, 2019; Winter, 2019). And after all, it is only logical that any study of "esotericism" also include the study of "apocrypha," which in ancient usage simply meant "hidden, secret, obscure things" before it came to have the specific sense of "secret, non-canonical books" (see LSJ 204b; Reed, 2015, pp. 407-412).

Thus, while we should be wary of speaking about "gnosis and esotericism in antiquity," we cannot avoid speaking about "Gnosticism, esotericism, and the ancient Mediterranean world," which is why many scholars are doing that already. The ancient Mediterranean sources which are so important for understanding modern discourse about esotericism - the interface of the early Christian literature called "Gnostic," the Hellenistic and late ancient flowering of revelatory (i.e., apocalyptic) literature, the works of the "Platonic Underworld," and the proximity of so much of this material to the world of ancient magic - may be usefully designated with the strategic essentialism "ancient (Mediterranean) esoteric traditions" (surveyed in Burns, 2015a). The utility of the phrase lies in its emphasis on the importance of competing claims to revelatory authority via ostensible possession of secret knowledge in a plurality of ongoing, rival constructions of tradition(s) in antiquity itself, constructions of tradition that, from the Renaissance to today, have been instrumental in further constructions of traditions of philosophy, theology, and esotericism (for a similar perspective put into practice in the study of ancient Hermetism, see Bull, 2015, esp. pp. 125-130).

History of reception and critical analysis of claims to revelatory authority and the concomitant constructions of tradition-approaches which are already flourishing in the study of ancient Mediterranean cultures (Burns and Renger, 2019) - furnish ideal, elegant means for tackling the complex problems with which ancient esoteric traditions present us. Reception-history steers us clear of simply utilizing emic terminology or presentations of evidence (on both the ancient and modern discourses; cf. the genealogical approach to the "Western" in "Western esotericism," in Strube, 2021). It reminds us, for instance, that what we call the Neoplatonism of the third century CE was a rather different thing than the Neoplatonism outlined by 
eighteenth-century historians of philosophy, and that the latter conditions our understanding of the former. This point is an essential corrective to the at times willful ignorance of many more traditional historians or philologists to the reception-history of their categories and artefacts (such as Layton, 1995, p. 335). Secondly, the problematic of the invention and construction of tradition is especially acute when it comes to questions of esotericism, where projections of modern or contemporary ideas onto an antique past in order to authorize them are omnipresent. The claims made by the professional scholar of antiquity in analysis of the ancient sources ought not echo or be easily mistaken for the claims made by the primary sources themselves in constructing the authority of revelation and/or tradition.

It is surely no coincidence that drawing lines of investigation along the tracks of histories of reception of these "ancient esoteric traditions" leads us into what are particularly vibrant spheres of scholarly research today that are distinct from the Yates paradigm and related models of the history of Western esotericism, but which also share so many historical roots with them. The modern discovery and "invention" of "Old Testament Pseudepigrapha" and "New Testament Apocrypha" has already been discussed; one could add to this the relationship between Gnosticism and early Jewish mysticism (Luttikhuizen, 2007; Burns, 2015a, pp. 26-27), the reception and relevance of Kabbalah in contemporary philosophy and even politics (Brown, 2019), or early Islamic philosophy and the phenomenon of "Islamic Gnosticism" (Amir-Moezzi, 2016). None of these phenomena are themselves "esoteric" or "esotericism" (for the cases of early Jewish mysticism and ancient Hermetism, see Boustan, 2015; Bull, 2015). Rather, they are phenomena that are more easily understood if one also masters evidence I have here loosely termed "ancient esoteric traditions," as well as its modern reception-histories and concomitant inventions of tradition, inventions that are inextricable from modern discourse about esotericism. It is here, and not in a modern reconstruction of "the esoteric gnosis" of yore, that there is a future for a most fruitful study of esotericism and antiquity.

\section{Bibliography}

Amir-Moezzi, M. (ed.) (2016) Esotérisme shi'ite: ses racines et ses prolongements. Bibliothèque de l'École des Hautes Études Sciences Religieuses 177. Paris and London: Bibliothèque de l'Ecole des Hautes Etudes; Institute of Ismaili Studies.

Asprem, E. (2012) Arguing with Angels: Enochian Magic and Modern Occulture. Albany: State University of New York Press. 
Asprem, E. (2021) "Rejected Knowledge Reconsidered: Some Methodological Notes on Esotericism and Marginality," in Asprem, E. and Strube, J. (eds.) New Approaches to the Study of Esotericism. Leiden and Boston: Brill, pp. 127-146.

Banner, N. (2018) Philosophic Silence and the "One" in Plotinus. Cambridge; New York: Cambridge University Press.

Boustan, R. (2015) "Secrets without Mystery: Esotericism in Early Jewish Mysticism," Aries: Journal for the Study of Western Esotericism, 15(1), pp. 10-15.

Bregman, J. (2016) "Synesius of Cyrene and the American 'Synesii," Numen, 63(2-3), pp. 299-323.

Broek, R.v.d. (2009) "The Birth of a Chair," in Hanegraaff, W. and Pijnenburg, J. (eds.) Hermes in the Academy: Ten Years' Study of Western Esotericism at the University of Amsterdam, Amsterdam: Amsterdam University Press, pp. 11-15.

Broek, R.v.d. (2013) Gnostic Religion in Antiquity. Cambridge: Cambridge University Press.

Brown, J. (2019) "La Perversión de la Cábala Judía': Gershom Scholem and AntiKabbalistic Polemic in the Argentine Catholic Nationalism of Julio Meinvielle," in GhaneaBassiri, K. and Robertson, P. (eds.) All Religion is Interreligion: Essays in Honor of Steven M. Wasserstrom, New York: Bloomsbury, pp. 65-73, 218-223.

Bull, C. (2015) "Ancient Hermetism and Esotericism," Aries: Journal for the Study of Western Esotericism, 15(1), pp. 109-135.

Burns, D. (2006) “The Chaldean Oracles of Zoroaster, Hekate's Couch, and Platonic Orientalism in Psellos and Plethon," Aries:Journal for the Study of Western Esotericism, 6(2), pp. 158-179.

Burns, D. (2007) "Seeking Ancient Wisdom in the New Age: New Age and Neo-Gnostic Commentators on the Gospel of Thomas," in von Stuckrad, K. and Hammer, O. (eds.) Polemical Encounters: Esoteric Discourse and its Others, Aries Book Series 6, Leiden: Brill, pp. 252-289.

Burns, D. (2014) Apocalypse of the Alien God: Platonism and the Exile of Sethian Gnosticism. Divinations. Philadelphia: University of Pennsylvania Press.

Burns, D. (2015a) "Ancient Esoteric Traditions: Mystery, Revelation, Gnosis," in Partridge, C. (ed.) The Occult World, Routledge Worlds, London: Routledge, pp. 17-33.

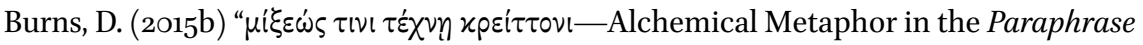
of Shem (NHC VII,1)," Aries: Journal for the Study of Western Esotericism, 15(1), pp. 79-106.

Burns, D. (2016) “Telling Nag Hammadi's Egyptian Story," Bulletin for the Study of Religion, 45(2), pp. $5^{-11 .}$

Burns, D. (2019a) "Gnosticism, Gnostics, and Gnosis," in Trompf, G., Johnston, J., and Mikkelsen, G. (eds.) The Gnostic World, Routledge Worlds, Abingdon; New York: Routledge, pp. 9-25. 
Burns, D. (2019b) "Weren't the Christians Up Against a Gnostic Religion? G.R.S. Mead at the Dawn of the Modern Study of Gnosticism," in Hanegraaff, W., Forshaw, P. and Pasi, M. (eds.) in Hermes Explains: Thirty-One Questions about Western Esotericism, Amsterdam: Amsterdam University Press, pp. 6o-69.

Burns, D. and N. Radulović (2019) “(Neo-)Bogomil Legends: The Gnosticizing Bogomils of the Twentieth-Century Balkans," in Burns, D. and Renger, A.-B. (eds.) New Antiquities: Transformations of Ancient Religion in the New Age and Beyond, London: Equinox Press, pp. 275-303.

Burns, D. and A.-B. Renger (2019) “Introduction: What Are New Antiquities?," in Burns, D. and Renger, A.-B. (eds.) New Antiquities: Transformations of Ancient Religion in the New Age and Beyond, London: Equinox Press, pp. 1-13.

Catana, L. (2013) "The Origin of the Division between Middle Platonism and Neoplatonism", Apeiron, 46(2), pp. 166-200.

Coblentz-Bautch, K. (2015) "Concealment, Pseudepigraphy and the Study of Esotericism in Antiquity," Aries: Journal for the Study of Western Esotericism, 15(1), pp. 1-9.

Costache, D. (2019) "Christian Gnosis: From Clement the Alexandrian to John Damascene," in Trompf, G., Johnston, J. and Mikkelsen, G. (eds.) The Gnostic World, Routledge Worlds, Abingdon; New York: Routledge, pp. 259-70.

DeConick, A. (2008) "Gnostic Letters from Bilthoven," in van Oort, J. (ed.) Gnostica, Judaica, Catholica: Collected Essays of Gilles Quispel. Nag Hammadi and Manichaean Studies 55, Leiden; Boston, pp. xv-xxi.

DeConick, A. (2016) The Gnostic New Age: How a Countercultural Spirituality Revolutionized Religion from Antiquity to Today. New York: Columbia University Press.

Dillon, J. (1977) The Middle Platonists. London: Duckworth.

Dillon, M. (2019) "The Impact of Scholarship on Contemporary 'Gnosticism(s)': A Case Study on the Apostolic Johannite Church and Jeremy Puma," in Burns, D. and Renger, A.-B. (eds.) New Antiquities: Transformations of Ancient Religion in the New Age and Beyond, London: Equinox Press, pp. 199-223.

Dodds, E. (1947) "Theurgy and its Relationship to Neoplatonism," Journal of Roman Studies, 37(1-2), pp. 55-69.

Dodds, E. (1977) Missing Persons: An Autobiography. Oxford: Clarendon Press.

Emmel, S. (2008) "The Coptic Gnostic Texts as Witnesses to the Production and Transmission of Gnostic (and Other) Traditions," in Frey, J. et al. (eds.) Das Thomasevangelium: Entstehung-Rezeption-Theologie, BZNW 157, Berlin: De Gruyter, pp. 33-49.

Faivre, A. (2010) “Le terme et la notion de 'Gnose' dans les courants ésotériques occidentaux modernes (essai de périodisation)," in Mahé, J.-P., Poirier, P.-H., and Scopello, M. (eds.) Les textes de Nag Hammadi: Histoire des religions et approches contemporaines. Paris: AIBL-Diffusion De Boccard: pp. 87-112.

Fowden, G. (1993) The Egyptian Hermes: A Historical Approach to the Late Pagan Mind. Princeton: Princeton University Press. 
Given, J. (2019) "Nag Hammadi at Eranos: Rediscovering Gnosticism among the Historians of Religion," in GhaneaBassiri, K. and Robertson, P. (eds.) All Religion is Interreligion: Essays in Honor of Steven M. Wasserstrom, New York: Bloomsbury, pp. 87-98, 231-237.

Gutierrez, C. (2014) Plato's Ghost: Spiritualism in the American Renaissance. Oxford: Oxford University Press.

Hammer, O. (2019) "The Jungian Gnosticism of the Ecclesia Gnostica," in Burns, D. and Renger, A.-B. (eds.) New Antiquities: Transformations of Ancient Religion in the New Age and Beyond, London: Equinox Press, pp. 175-198.

Hanegraaff, W. (2012) Esotericism and the Academy: Rejected Knowledge in Western Culture, Cambridge: Cambridge University Press.

Hanegraaff, W. (2016) "Gnosis," in Magee, G. (ed.) The Cambridge Handbook of Western Mysticism and Esotericism, Cambridge: Cambridge University, pp. 381-392.

Hankey, W. (2007) “Re-Evaluating E. R. Dodds' Platonism," Harvard Studies in Classical Philology 103, pp. 499-541.

Johnson, A. (2013) Religion and Identity in Porphyry of Tyre: The Limits of Hellenism in Late Antiquity. Cambridge: Cambridge University Press.

Johnston, J. (2019) "Binding Images: The Contemporary Use and Efficacy of Late Antique Ritual Sigils, Spirit-Beings, and Design Elements," in Burns, D. and Renger, A.-B. (eds.) New Antiquities: Transformations of Ancient Religion in the New Age and Beyond, London: Equinox Press, pp. 254-274.

King, K. (2003) What is Gnosticism? Cambridge: Harvard University Press.

Koslowski, P. (1988) Gnosis und Mystik in der Geschichte der Philosophie. Zürich: Artemis Verlag.

Kreps, A. (2019) "Reading History with the Essenes of Elmira," in Burns, D. and Renger, A.-B. (eds.) New Antiquities: Transformations of Ancient Religion in the New Age and Beyond, London: Equinox Press, pp. 149-174.

Lamberton, R. (1986) Homer the Theologian: Neoplatonist Allegorical Reading and the Growth of the Epic Tradition. Transformation of the Classical Heritage 9. Berkeley: University of California Press.

Layton, B. "Preface," in Layton, B. (ed.) in The Rediscovery of Gnosticism: Proceedings of the International Conference on Gnosticism at Yale, New Haven, Connecticut, March 28-31, 1978, Numen Book Series, Leiden: Brill, pp. 1:ix-xii.

Layton, B. (1995) "Prolegomena to the Study of Ancient Gnosticism," in White, M. and Yarbrough, L. (eds.) The Social World of the First Christians: Essays in Honor of Wayne Meeks, Minneapolis: Fortress Press, pp. 334-35o.

Lowe, N.J. (2019) "The Rational Irrationalist: Dodds and the Paranormal," in Stray, C., Pelling, C. and Harrison, S. (eds.) Rediscovering E. R. Dodds: Scholarship, Education, Poetry, and the Paranormal, Oxford: Oxford University Press, pp. 88-115. 
Luttikhuizen, G. (2007) "Monism and Dualism in Jewish-Mystical and Gnostic Ascent Texts," in Hilhorst, A., Puech, É. and Tigchelaar, E. (eds.) Flores Florentino: Dead Sea Scrolls and Other Early Jewish Studies in Honour of Florentino García Martínez, Journal for the Study of Judaism Supplement 122, Leiden; Boston: Brill, pp. 749-775.

Majercik, R. (1989) The Chaldean Oracles: Text, Translation, and Commentary. Studies in Greek and Roman Religion 5. Leiden: Brill.

Marx-Wolf, H. (2016) Spiritual Taxonomies and Ritual Authority: Platonists, Priests, and Gnostics in the Third Century C.E. Divinations. Philadelphia: University of Pennsylvania Press.

Mazur, A. J. (2020) The Platonizing Elements of Plotinus's Mysticism. Rev. ed. Dylan Burns, et al. Nag Hammadi and Manichaean Studies 98. Leiden: Brill.

Mead, G. (19o6) Fragments of a Faith Forgotten [2nd ed.], London; Benares: Theosophical Publishing Society.

Nelson, V. (2003) The Secret Life of Puppets. Cambridge: Harvard University Press.

Perkams, M. (2017) "Einheit und Vielfalt der Philosophie von der Kaiserzeit zur ausgehenden Antike," in Riedweg, C. (ed.) PHILOSOPHIA in der Konkurrenz von Schulen, Wissenschaften Und Religionen: Zur Pluralisierung des Philosophiebegriffs in Kaiserzeit Und Spätantike, Philosophie der Antike 34, Berlin; Boston: De Gruyter, pp. 3-32.

Places, É.d. (1973) Numénius: Fragments. Collection des universités de France Série grecque 226. Paris: Les Belles Lettres.

Quispel, G. (2008) "Gnosis and Culture," in van Oort, J. (ed.) Gnostica, Judaica, Catholica. Collected Essays of Gilles Quispel, Nag Hammadi and Manichaean Studies 55, Leiden; Boston, pp. 141-153.

Reed, A. (2009) “The Modern Invention of 'Old Testament Pseudepigrapha,'” Journal of Theological Studies, 6o(2), pp. 403-436.

Reed, A. (2015) “The Afterlives of New Testament Apocrypha," Journal of Biblical Literature, 133(2), pp. 401-425.

Saif, L. (2021) “That I Did Love the Moor to Live with Him': Islam in/and the Study of "Western Esotericism,"' in Asprem, E. and Strube, J. (eds.) New Approaches to the Study of Esotericism. Leiden and Boston: Brill, pp. 67-87.

Segal, A. (1980) "Heavenly Ascent in Hellenistic Judaism, Early Christianity and their Environment," Aufstieg und Niedergang der Römischen Welt II.23.2, pp. 1333-1394.

Shaw, G. (2019) “Can We Recover Gnosis Today?," Gnosis: Journal of Gnostic Studies, 4(1), pp. $67-8$ o.

Soares Santoprete, L. (2016) “Tracing the Connections between 'Mainstream' Platonism (Middle- and Neo-Platonism) and 'Marginal' Platonism (Gnosticism, Hermeticism and the Chaldean Oracles) with Digital Tools: the Database, the Bibliographical Directory, and the Research Blog The Platonisms of Late Antiquity," in Seng, H. 
and Gasparro, G.S. (eds.) Theologische Orakel in der Spätantike, Bibliotheca Chaldaica 5 , Heidelberg: Universitätsverlag Winter, pp. 9-45.

Stone, M. (2018) Secret Societies in Ancient Judaism. Oxford: Oxford University Press.

Stoyanov, Y. (2000) The Other God:Dualist Religions from Antiquity to the Cathar Heresy. London; New Haven: Yale University Press.

Strube, J. (2016) Sozialismus, Katholizismus und Okkultismus im Frankreich des 19. Jahrhunderts: Die Genealogie der Schriften von Eliphas Lévi. Religionsgeschichtliche Versuche und Vorarbeiten 69. Berlin; Boston: De Gruyter.

Strube, J. (2017a) “The 'Baphomet' of Eliphas Lévi: Its Meaning and Historical Context," Correspondences, 4, pp. 37-79.

Strube, J. (2017b) "Revolution, Illuminismus und Theosophie: Eine Genealogie der 'häretischen' Historiographie des frühen französischen Sozialismus und Kommunismus," Historische Zeitschrift, 304(1), pp. 50-89.

Strube, J. (2021) "Towards the Study of Esotericism without the 'Western": Esotericism from the Perspective of a Global Religious History," in Asprem, E. and Strube, J. (eds.) New Approaches to the Study of Esotericism. Leiden and Boston: Brill, pp. $45^{-66 .}$

Stuckrad, K.v. (2010) Locations of Knowledge in Medieval and Early Modern Europe: Esoteric Discourse and Western Identities. Brill's Studies in Intellectual History 186. Leiden: Brill.

Stuckrad, K.v. (2013) "Afterword: Mysticism, Gnosticism, and Esotericism as Entangled Discourses," in DeConick, A. and Adamson, G. (eds.) Histories of the Hidden God: Concealment and Revelation in Western Gnostic, Esoteric, and Mystical Traditions, Durham: Acumen, pp. 312-319.

Stuckrad, K.v. (2015) "Ancient Esotericism, Problematic Assumptions, and Conceptual Trouble," Aries: Journal for the Study of Western Esotericism, 15(1), pp. 16-20.

Tanaseanu-Döbler, I. (2013) Theurgy in Late Antiquity: The Invention of a Ritual Tradition. Göttingen: Vandenhoeck \& Ruprecht.

Tommasi, C.O. (2016) "Some Reflections on Antique and Late Antique Esotericism: between Mainstream and Counterculture," in Seng, H., Soares Santoprete, L.G., and Tommasi, C.O. (eds.) Formen und Nebenformen des Platonismus in der Spätantike, Bibliotheca Chaldaica 6, Heidelberg: Universitätsverlag Winter, pp. 9-36.

Turner, J. (2016) "The Chaldaean Oracles: A Pretext for the Sethian Apocalypse Allogenes?," in Seng, H. and Gasparro, G.S. (eds.) Theologische Orakel in der Spätantike, Bibliotheca Chaldaica 5, Heidelberg: Universitätsverlag Winter, pp. 89-114.

Vander Stichele, C. and Scholz, S. (eds.) (2014) Hidden Truths from Eden: Esoteric Readings of Genesis 1-3. Semeia Studies 76. Atlanta: Society of Biblical Literature.

Versluis, A. (2019) “What Is Gnosis? An Explanation," Gnosis: Journal of Gnostic Studies, 4(1), pp. 81-98. 
Walbridge, J. (2001) The Wisdom of the Mystic East: Suhrawardī and Platonic Orientalism. Albany: State University of New York Press.

Williams, Michael (1996) Rethinking “Gnosticism”: Arguments for Dismantling a Dubious Category. Princeton: Princeton University Press.

Winter, F. (2019) "Studying the 'Gnostic Bible': Samael Aun Weor and the Pistis Sophia," in Burns, D. and Renger, A.-B. (eds.) New Antiquities: Transformations of Ancient Religion in the New Age and Beyond, London: Equinox Press, pp. 149-174.

Yates, F. (1964) Giordano Bruno and the Hermetic Tradition. London: Routledge and Kegan Paul. 